Article

\title{
Effect of Instant Controlled Pressure-Drop (DIC), Cooking and Germination on Non-Nutritional Factors of Common Vetch (Vicia sativa spp.)
}

\author{
Angel I. Hernandez-Aguirre, Carmen Téllez-Pérez, Alejandra San Martín-Azócar \\ and Anaberta Cardador-Martínez *(D) \\ Departamento de Bioingenierias, Tecnologico de Monterrey, Monterrey 76158, Mexico; \\ ibq.anivhdez@gmail.com (A.I.H.-A.); ctellezpe@tec.mx (C.T.-P.); alsmartin@tec.mx (A.S.M.-A.) \\ * Correspondence: mcardador@tec.mx; Tel.:+52-442-161-0181
}

Academic Editors: Carmen Cuadrado and Karim Allaf

Received: 13 November 2019; Accepted: 20 December 2019; Published: 30 December 2019

check for updates

\begin{abstract}
Legumes are widely consumed by humans, being an important source of nutrients; however, they contain non-nutritional factors (NNFs), such as phytic acid $\left(\mathrm{IP}_{6}\right)$, raffinose, stachyose, total phenolic compounds, condensed tannins, and flavonoids, that have negative effects on human health. Although vetches (Vicia sativa) are widely cultivated, they are not intended for human feeding due to their contents of NNF. Usually, the NNF are removed by cooking or germinating; however, germination is a process that requires extended time, and cooking may compromise the viability of some nutrients. To promote vetches for human consumption, the effect of the Instant Controlled Pressure Drop (DIC) process was studied as an alternative to cooking and germinating to decrease NNF contents. Results showed that compared to raw vetches, DIC treatment reduced total phenolic compounds (48\%), condensed tannins $(28 \%)$, flavonoids $(65 \%)$, IP6 $(92 \%)$, raffinose $(77 \%)$, and stachyose $(92 \%)$. These results are very similar to the ones achieved by traditional ways of removing NNF.
\end{abstract}

Keywords: non-nutritional factors (NNFs); vetches (Vicia sativa spp.); instant controlled pressure drop (DIC); cooking; germination; total phenolic compounds; tannins; oligosaccharides; phytic acid

\section{Introduction}

According to the Food and Agricultural Organization (FAO), pulses are dry seeds of plants belonging to the Leguminosae family. Within the most common pulses, stand out beans, broad beans, peas, chickpeas, cowpeas, pigeon peas, lentils, Bambara beans, lupins, vetches, and other minor legumes [1]. It is known that pulses represent an important source of proteins and nutrients necessary for human feeding [2]. Moreover, numerous studies suggest that consumption of legumes may have potential health benefits as reducing the risk of cardiovascular diseases [3], cancer [4], diabetes [5], hypertension [6], among others. In México, according to FAO, the most consumed legume are common beans (Phaseolus vulgaris); nevertheless, they present a low crop yield [7]. On the other hand, Vicia sativa spp. (common vetch) is not commonly used for human feeding, but is widely cultivated as soil improvement and as feed for livestock due to their high content of proteins and other nutrients [8]. Moreover, by comparing to common beans, vetches have a better crop yield [7]. However, the use of pulses such as vetches is reduced due to the presence of compounds known as Non-nutritional factors (NNF). NNF are defined as compounds that reduce the nutrient utilization and/or food intake of plants or plant products used as human foods or animal feeds [9]. Among the NNF identified on pulses, phytic acid, oligosaccharides, and phenolic compounds are the most commonly linked to the most undesirable physiological reactions such as flatulence, inhibition of enzymes, or vitamin absorption 
and low digestibility [8]. Phytic acid $\left(\mathrm{IP}_{6}\right)$ is one of the most common heat resistant NNF in plants. $\mathrm{IP}_{6}$ chelates micronutrients and reduces their bioavailability for monogastric animals, including humans, because of the lack of phytase enzyme in their digestive tract [10]. Oligosaccharides, such as raffinose and stachyose, are well known to cause flatulence in mammals that have no $\alpha$-galactosidase [11]. These saccharides contain one, two or three galactose units joined to $\alpha-1-6$ galactosidic linkages. The lack of $\alpha$-galactosidase leads to the production of flatus gases $\left(\mathrm{H}_{2}, \mathrm{CO}_{2}\right.$ and small amounts of $\mathrm{CH}_{4}$ ), diarrhea, and discomfort [12]. Phenols bind to positively charged proteins, amino acids, and/or multivalent cations or minerals such as $\mathrm{Fe}, \mathrm{Ca}$, and $\mathrm{Zn}$ in foods, and decrease their digestibility [13].

However, NNF have also shown health benefits as the improving of essential minerals bioavailability [14], the reduction of the blood glucose and insulin responses to starchy foods and/or the plasma cholesterol and triglycerides [15], the prevention of kidney stone formation, caries, atherosclerosis, and coronary heart disease as well as against of cancer [16]. According to Muzquiz, et al. [17], exposure time, biochemistry, concentration, and interaction with other dietary components, may influence the balance between beneficial or deleterious effects of NNF consumption. Therefore, a relevant challenge is to determine the adequate processing conditions to preserve the adequate amount of NNF in legumes to make the most of the positive effects in human health and to reduce as far the negative effects [18-20].

To reduce the NNF of pulses, various treatments such as soaking, fermentation, germination, washing, heating, among others, have been applied [21-27]. Among all these treatments, heat is the most used, with cooking times between 20 to $120 \mathrm{~min}$. However, the final nutritional value of legumes can be damaged in the function of the type and intensity of heating [28-30]. Then the use of HTST (High Temperature/Short Time) treatments becomes promising to reduce the non-nutritional factors [11].

The instant controlled pressure drop technique, better-known by its French acronym Détente Instantanée Contrôlée (DIC) is an HTST treatment. It consists of subjecting a product to a high pressure saturated dry steam (almost between 100 and $1000 \mathrm{kPa}$ according to the product and the objectives) for a short period (seconds), followed by an abrupt pressure drop towards a vacuum (about $5 \mathrm{kPa}$ ). This thermo-hydro-mechanical process induces instant auto vaporization of a quantity of the product water, which provokes a controlled expansion and an immediate cooling of treated products, which stops thermal degradation [31]. The effect of DIC treatment has been previously evaluated by Haddad and Allaf [32] and Pedrosa et al. [11] on several NNF of soybean, lupin, lentil, chickpea, and roasted peanut. Their results showed an important reductions of the NNF. Figure 1 shows the schematic time-pressure profiles of a DIC processing cycle.

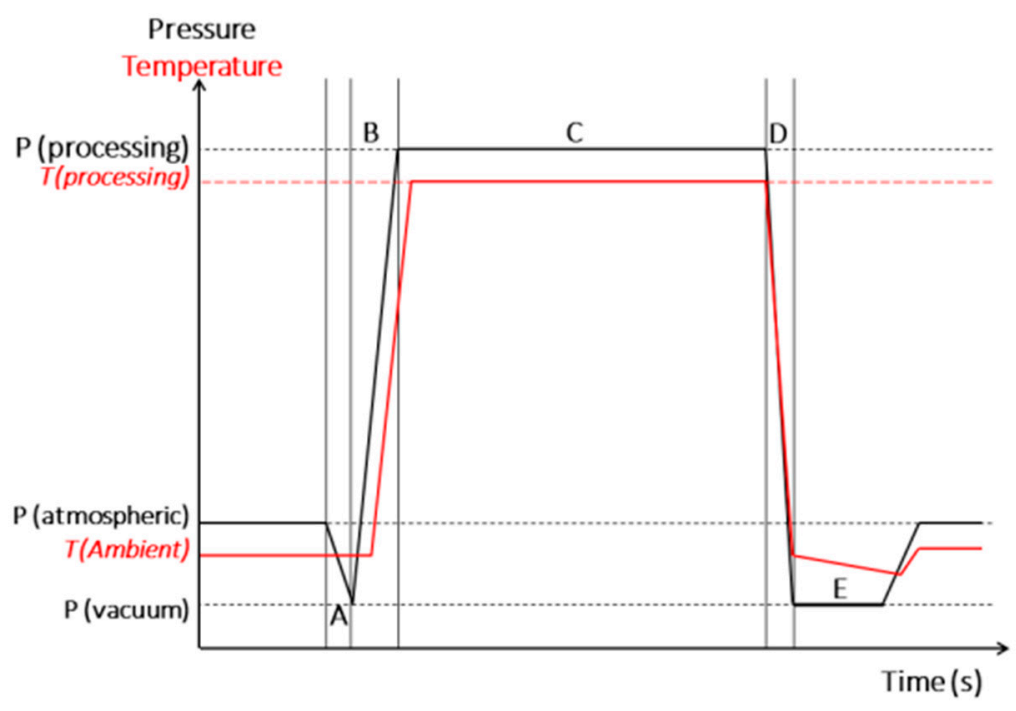

Figure 1. Schematic time-pressure profiles of a DIC processing cycle. 
On the other hand, germination has also been applied to decrease the NNF of pulses [33-36]. Germination starts when the dry seed begins to take up water and is completed when the embryonic axis elongates [37]. However, the effect of germination depends on the type of legume and the conditions and duration of the germination process $[35,36,38]$.

Therefore, this work aims to compare the impact of the instant controlled pressure drop (DIC) technique to cooking, and germination, on the reduction of NNF of vetches, to lay the basis for possible future use as human food.

\section{Results and Discussion}

\subsection{Chemical Proximate Analysis}

Table 1 shows the average contents of moisture, ashes, crude fiber, total nitrogen, and ethereal extract of non-treated flours. These results are similar compared to the study of bitter vetch seeds performed by Sadeghi et al. [25]; the slight differences can be attributed to the growing conditions and postharvest handling. Proximate analysis performed on others legume flours (chickpea, pea, common bean and lentils), showed that by comparing these legumes to vetches, the latter presented higher contents of crude fiber (5.69 to $10.4 \mathrm{~g} / 100 \mathrm{~g}$ dry matter), ashes (3.12 to $4 \mathrm{~g} / 100 \mathrm{~g}$ dry matter) and lipids content ( 2.34 to $6.73 \mathrm{~g} / 100 \mathrm{~g}$ dry matter), and lower protein content (18.5 to $23.7 \mathrm{~g} / 100 \mathrm{~g}$ dry matter) [39].

Table 1. Chemical proximate analysis of non-treated vetch flour.

\begin{tabular}{cc}
\hline Moisture (\%) & $15.0 \pm 0.5$ \\
Ashes (\%) & $2.5 \pm 0.1$ \\
Crude fiber (\%) & $12.1 \pm 0.6$ \\
Total nitrogen (\%) & $16.1 \pm 0.9$ \\
Ethereal extract (\%) & $5.0 \pm 0.9$ \\
Nitrogen-free extract (\%) & 49.3 \\
\hline${ }^{1}$ Values are expressed as means of three replicates \pm SD. Calculated by difference.
\end{tabular}

\subsection{Effect of Instant Controlled Pressure Drop, Cooking and Germination on Non-Nutritional Factors} of Vetches

Total phenolics content (TPC), condensed tannins content (CT), total flavonoids content (TFC), phytic acid content $\left(\mathrm{IP}_{6}\right)$, raffinose content, and stachyose content of DIC, cooked, germinated and raw vetches are shown on Table 2. Raw vetch flour have shown total phenolics compounds of $191.4 \mathrm{mg}$ eq. of gallic acid/g dry basis; condensed tannins of $12.31 \mathrm{mg}$ eq. of catechin/g dry basis; flavonoids of $16.55 \mathrm{mg}$ eq. of rutin/g dry basis; phytic acid (expressed as $\mathrm{mg} / \mathrm{g}$ dry basis) of 13.5; raffinose (expressed as $\mathrm{mg} / \mathrm{g}$ dry basis) of 7.86; and stachyose of $24.67 \mathrm{mg} / \mathrm{g}$ dry basis. 
Table 2. Total phenolics content, condensed tannins content, total flavonoids content, phytic acid content, raffinose and Stachyose content of DIC, cooked, germinated and raw vetches.

\begin{tabular}{|c|c|c|c|c|c|c|}
\hline Sample & $\mathrm{TPC}^{1}(\mathrm{mg} / \mathrm{g})$ & $\mathrm{CT}^{2}(\mathrm{mg} / \mathrm{g})$ & $\mathrm{TFC}^{3}(\mathrm{mg} / \mathrm{m})$ & $\mathrm{IP}_{6}{ }^{4}(\mathrm{mg} / \mathrm{g})$ & Raffinose (mg/g) & Stachyose $(\mathrm{mg} / \mathrm{g})$ \\
\hline DIC1 & $150.25 \pm 0.22$ & $10.16 \pm 0.90$ & $12.13 \pm 0.22$ & $10.40 \pm 0.62$ & $4.32 \pm 0.03$ & $47.20 \pm 1.10$ \\
\hline DIC2 & $129.20 \pm 0.45$ & $9.10 \pm 0.70$ & $12.35 \pm 0.45$ & $8.48 \pm 0.71$ & $4.98 \pm 0.08$ & $38.50 \pm 0.60$ \\
\hline DIC3 & $112.54 \pm 0.41$ & $9.41 \pm 0.90$ & $5.68 \pm 0.04$ & $11.87 \pm 0.80$ & $6.67 \pm 0.11$ & $53.82 \pm 1.40$ \\
\hline DIC4 & $178.96 \pm 0.46$ & $11.54 \pm 0.70$ & $6.45 \pm 0.03$ & $10.04 \pm 0.39$ & $4.38 \pm 0.07$ & $45.73 \pm 1.12$ \\
\hline DIC5 & $99.53 \pm 0.17$ & $8.83 \pm 0.80$ & $11.17 \pm 0.24$ & $0.99 \pm 0.11$ & $2.25 \pm 0.01$ & $4.41 \pm 0.22$ \\
\hline DIC6 & $147.38 \pm 0.22$ & $9.96 \pm 1.02$ & $11.78 \pm 0.14$ & $1.02 \pm 0.32$ & $1.78 \pm 0.00$ & $4.66 \pm 0.33$ \\
\hline DIC7 & $98.38 \pm 0.27$ & $10.16 \pm 0.81$ & $14.38 \pm 0.17$ & $10.38 \pm 1.17$ & $4.77 \pm 0.45$ & $47.69 \pm 0.77$ \\
\hline DIC8 & $164.60 \pm 0.22$ & $11.43 \pm 0.83$ & $6.01 \pm 0.05$ & $5.09 \pm 0.72$ & $2.00 \pm 0.04$ & $23.05 \pm 0.56$ \\
\hline DIC9 & $126.13 \pm 0.12$ & $10.64 \pm 1.17$ & $5.83 \pm 0.03$ & $5.08 \pm 0.47$ & $1.89 \pm 0.05$ & $23.11 \pm 0.14$ \\
\hline DIC10 & $152.74 \pm 0.10$ & $10.30 \pm 0.66$ & $5.40 \pm 0.07$ & $10.41 \pm 1.25$ & $4.76 \pm 0.03$ & $47.51 \pm 0.36$ \\
\hline DIC11 & $161.16 \pm 0.54$ & $11.05 \pm 0.87$ & $15.11 \pm 0.77$ & $6.28 \pm 0.16$ & $4.68 \pm 0.01$ & $53.15 \pm 0.14$ \\
\hline DIC12 & $185.47 \pm 0.45$ & $12.79 \pm 0.92$ & $13.98 \pm 0.87$ & $11.53 \pm 2.16$ & $6.89 \pm 0.44$ & $28.26 \pm 0.22$ \\
\hline DIC13 & $147.76 \pm 0.44$ & $10.18 \pm 0.60$ & $5.89 \pm 0.11$ & $10.49 \pm 0.43$ & $2.92 \pm 0.01$ & $47.57 \pm 0.47$ \\
\hline C45 & $132.45 \pm 0.13$ & $10.67 \pm 0.33$ & $11.68 \pm 1.01$ & $1.65 \pm 0.91$ & $0.68 \pm 0.02$ & $7.54 \pm 0.50$ \\
\hline C60 & $115.80 \pm 0.36$ & $10.12 \pm 1.81$ & $8.06 \pm 0.23$ & $0.55 \pm 0.12$ & $0.49 \pm 0.02$ & $2.57 \pm 0.07$ \\
\hline C90 & $212.26 \pm 0.98$ & $10.02 \pm 1.27$ & $8.47 \pm 0.11$ & $0.59 \pm 0.07$ & $0.46 \pm 0.05$ & $2.64 \pm 0.01$ \\
\hline $\mathrm{C} 120$ & $173.22 \pm 0.78$ & $9.80 \pm 1.39$ & $8.75 \pm 0.19$ & $0.63 \pm 0.08$ & $0.31 \pm 0.06$ & $3.07 \pm 0.00$ \\
\hline Germinated & $136.66 \pm 0.78$ & $11.76 \pm 0.70$ & $11.68 \pm 0.53$ & $0.57 \pm 0.08$ & $0.31 \pm 0.04$ & $2.51 \pm 0.17$ \\
\hline
\end{tabular}

\subsubsection{Effect of Instant Controlled Pressure Drop Treatment on NNF of Vetches}

To better evaluate the effect of DIC treatment on the total phenolic compounds, condensed tannins, flavonoids, phytic acid, raffinose, and stachyose of vetch flours, obtained results were expressed as percentage respect to NNF of non-treated vetch flour (Table 3).

Table 3. Effect of DIC over total phenolics, condensed tannins, and flavonoids.

\begin{tabular}{ccccccc}
\hline Sample & $\begin{array}{c}\text { Total Phenolics } \\
\text { Reduction } \\
\mathbf{( \% )}\end{array}$ & $\begin{array}{c}\text { Tannins } \\
\text { Reduction } \\
\mathbf{( \% )}\end{array}$ & $\begin{array}{c}\text { Flavonoids } \\
\text { Reduction } \\
\mathbf{( \% )}\end{array}$ & $\begin{array}{c}\text { Phytates } \\
\text { Reduction } \\
\mathbf{( \% )}\end{array}$ & $\begin{array}{c}\text { Raffinose } \\
\text { Reduction } \\
\mathbf{( \% )}\end{array}$ & $\begin{array}{c}\text { Stachyose } \\
\text { Reduction } \\
(\%)\end{array}$ \\
\hline DIC1 & $21.5^{\mathrm{cd}}$ & $17.4^{\mathrm{b}}$ & $26.7^{\mathrm{abc}}$ & $23.0^{\mathrm{c}}$ & $45.0^{\mathrm{a}}$ & $23.0^{\mathrm{bc}}$ \\
DIC2 & $32.5^{\mathrm{de}}$ & $26.0^{\mathrm{b}}$ & $25.4^{\mathrm{abc}}$ & $37.2^{\mathrm{e}}$ & $36.6^{\mathrm{c}}$ & $37.2^{\mathrm{d}}$ \\
DIC3 & $4^{\mathrm{b}} .^{\mathrm{ef}}$ & $23.5^{\mathrm{b}}$ & $65.7^{\mathrm{c}}$ & $12.1^{\mathrm{a}}$ & $15.1^{\mathrm{b}}$ & $12.2^{\mathrm{a}}$ \\
DIC4 & $5.6^{\mathrm{ab}}$ & $6.2^{\mathrm{ab}}$ & $61.0^{\mathrm{abc}}$ & $25.6^{\mathrm{d}}$ & $44.3^{\mathrm{e}}$ & $25.4^{\mathrm{c}}$ \\
DIC5 & $48.0^{\mathrm{ef}}$ & $28.2^{\mathrm{b}}$ & $32.5^{\mathrm{abc}}$ & $92.7^{\mathrm{h}}$ & $71.4^{\mathrm{g}}$ & $92.8^{\mathrm{g}}$ \\
DIC6 & $23.9^{\mathrm{cd}}$ & $19.0^{\mathrm{ab}}$ & $28.8^{\mathrm{abc}}$ & $92.4^{\mathrm{h}}$ & $77.4^{\mathrm{i}}$ & $92.4^{\mathrm{g}}$ \\
DIC7 & $48.6^{\mathrm{f}}$ & $17.4^{\mathrm{b}}$ & $13.1^{\mathrm{a}}$ & $23.1^{\mathrm{c}}$ & $39.3^{\mathrm{d}}$ & $22.2^{\mathrm{b}}$ \\
DIC8 & $14.0^{\mathrm{abc}}$ & $7.1^{\mathrm{ab}}$ & $63.7^{\mathrm{bc}}$ & $62.3^{\mathrm{g}}$ & $74.5^{\mathrm{h}}$ & $62.4^{\mathrm{f}}$ \\
DIC9 & $34.1^{\mathrm{de}}$ & $13.5^{\mathrm{ab}}$ & $64.8^{\mathrm{bc}}$ & $62.4^{\mathrm{g}}$ & $75.9^{\mathrm{hi}}$ & $62.3^{\mathrm{f}}$ \\
DIC10 & $20.2^{\mathrm{abc}}$ & $16.3^{\mathrm{ab}}$ & $67.4^{\mathrm{bc}}$ & $22.9^{\mathrm{c}}$ & $39.4^{\mathrm{d}}$ & $22.5^{\mathrm{bc}}$ \\
DIC11 & $15.8^{\mathrm{abc}}$ & $10.2^{\mathrm{ab}}$ & $8.7^{\mathrm{a}}$ & $53.5^{\mathrm{f}}$ & $40.5^{\mathrm{d}}$ & $13.3^{\mathrm{a}}$ \\
DIC12 & $3.1^{\mathrm{a}}$ & $-4^{\mathrm{a}}$ & $15.5^{\mathrm{ab}}$ & $14.6^{\mathrm{b}}$ & $12.3^{\mathrm{a}}$ & $53.9^{\mathrm{e}}$ \\
DIC13 & $22.8^{\mathrm{cd}}$ & $17.2^{\mathrm{ab}}$ & $64.4^{\mathrm{bc}}$ & $22.3^{\mathrm{c}}$ & $62.9^{\mathrm{f}}$ & $22.4^{\mathrm{bc}}$ \\
\hline
\end{tabular}

Values are expressed as means of three replicates. Letters in the same column indicate significative differences. DIC = Instant Controlled Pressure Drop treatments, C= Cooking treatments.

The most significant reductions for total phenolics (48\%), condensed tannins (28\%), phytic acid $(92 \%)$, raffinose $(77 \%)$, and stachyose $(92 \%)$ are observed at $0.41 \mathrm{MPa}$. In the case of flavonoids, the most significant reduction $(67.43 \%)$ was found between 0.3 to $0.33 \mathrm{MPa}$ and $195 \mathrm{~s}$. For raffinose, the highest reduction $(77.42 \%)$ was obtained under $0.41 \mathrm{MPa}$ and $78 \mathrm{~s}$.

Figure 2 shows the Pareto charts of the significative effects of DIC treatments, and Figure 3 shows the surface response graphs of NNFs reduction caused by DIC treatment. Pareto charts (Figure 2), 
shows the impact of DIC operating parameters (saturated steam pressure and treatment time) on the reduction percentage of NNFs. In the case of total phenolics (Figure 2a) and condensed tannins (Figure 2b), it can be observed that both pressure and time have a significant effect on the reduction of these NNFs. In fact, the higher the steam pressure and treatment time, the higher the reduction of total phenolics and condensed tannins (Figure 3a,b, respectively). Figure 2c illustrates the significant quadratic effect of saturated steam pressure on $\mathrm{IP}_{6}$. By exploring the response surface graph (Figure 3c), it can be observed that under the higher and lower values of saturated steam pressure, a significant $\mathrm{IP}_{6}$ reduction can be obtained. With respect to stachyose, Figure $2 \mathrm{~d}$ shows that both the quadratic effect of saturated steam pressure and the quadratic effect of treatment time have a significant impact on the reduction of stachyose. Moreover, Figure 3d shows that an important reduction of stachyose can be achieved under high values of the saturated steam pressure and low values of treatment time. In the case of flavonoids and raffinose reduction, it can be observed that under the selected operating conditions of steam pressure and time, neither P nor t presents a significant effect on both response variables. Then, the best DIC treatment condition to reduce the most NNF of vetches was DIC 5 (0.41 MPa and $312 \mathrm{~s})$.
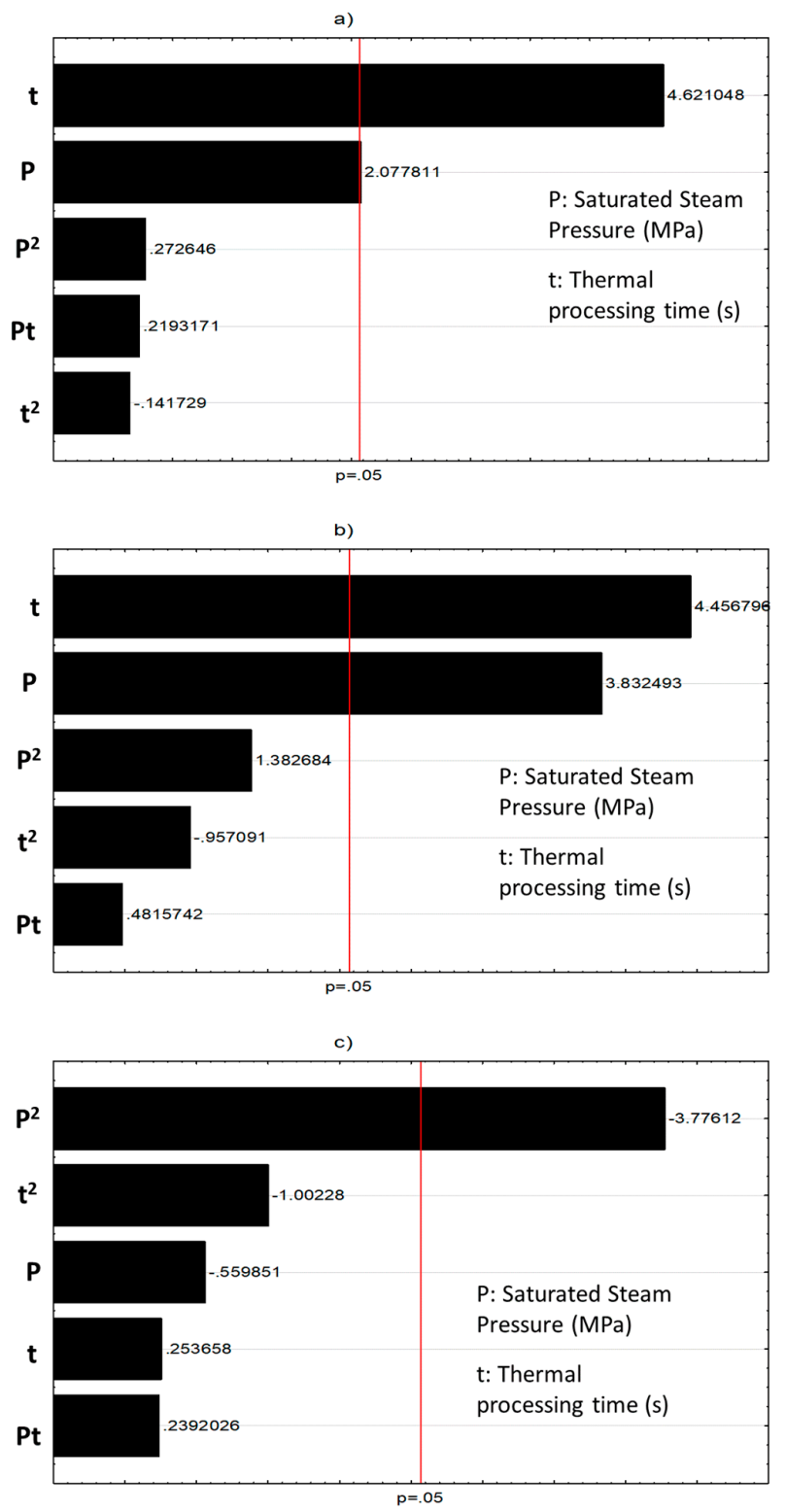

Figure 2. Cont. 


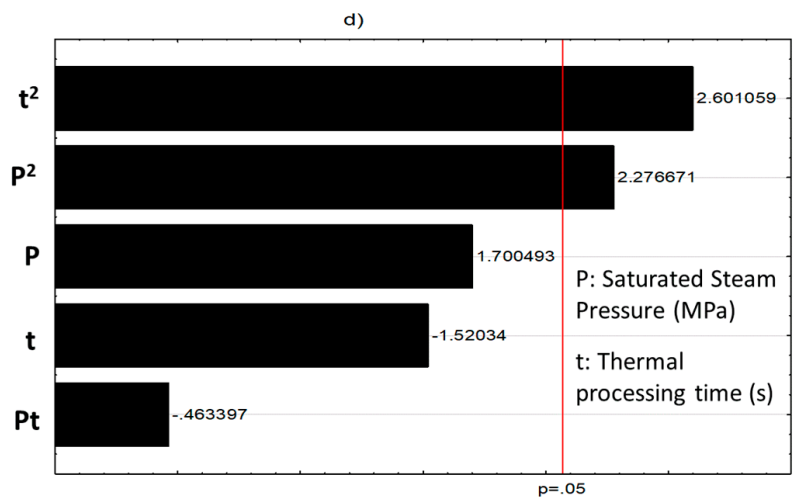

Figure 2. Pareto charts of significative effects on DIC treatments. (a) Total phenolics reduction, (b) Condensed tannins reduction, (c) $\mathrm{IP}_{6}$ reduction, (d) Stachyose reduction.

a)

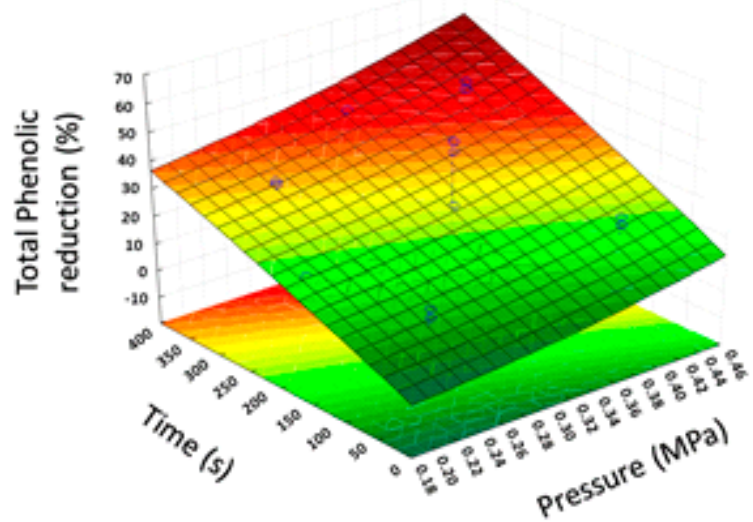

TPC reduction $(\%)=-0.55881-18.69485 * \mathrm{P}+105.73812^{*} \mathrm{P}^{2}+0.08891 * \mathrm{~T}-0.00003^{*} \mathrm{~T}^{2}+$ $0.08380 * T * P$

b)

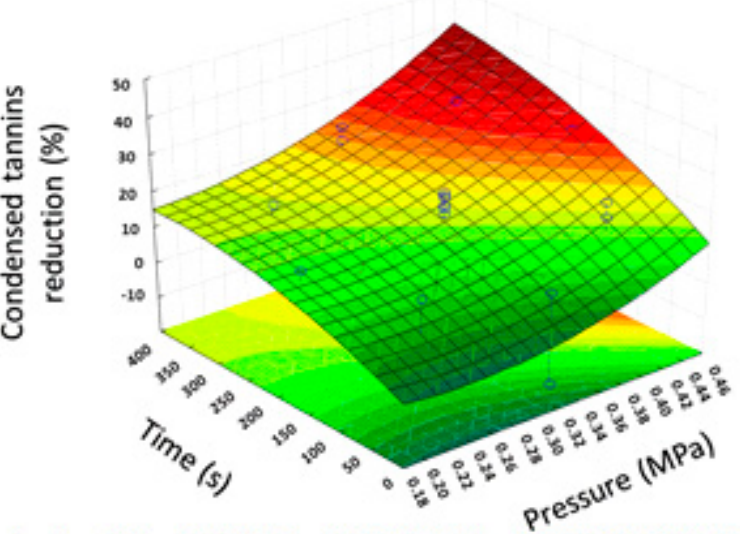

CT reduction $(\%)=15.31835-152.82595 * \mathrm{P}+312.7827 * \mathrm{P}^{2}+0.06946 * \mathrm{~T}-0.00012 * \mathrm{~T}^{2}+$ $0.10733^{*} \mathrm{~T} * \mathrm{P}$

Figure 3. Cont. 


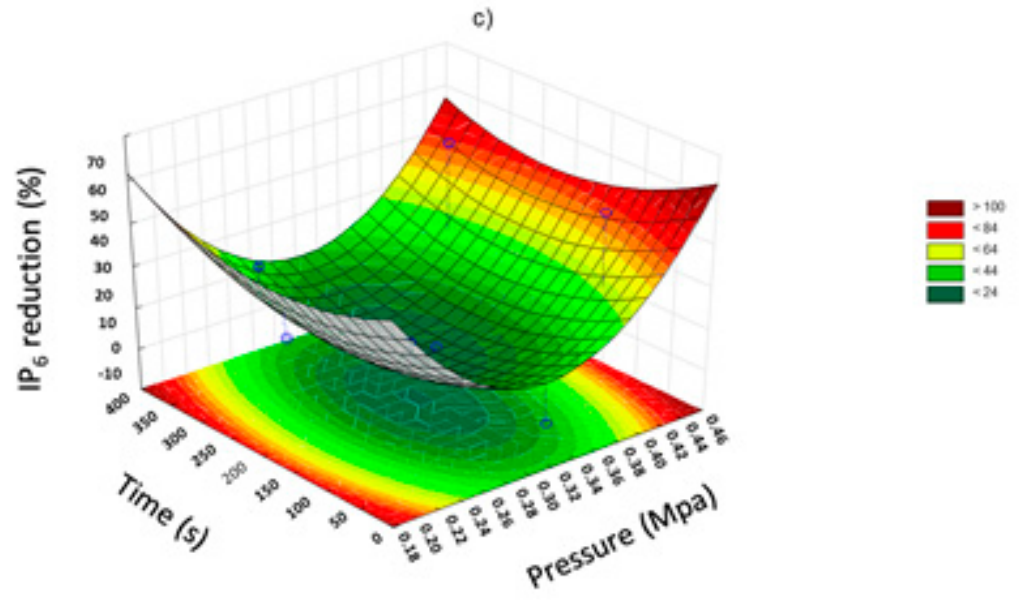

IP6 reduction $(\%)=336.83231-1884.76670^{*} \mathrm{P}+3012.65222^{*} \mathrm{P}^{2}-0.11876^{*} \mathrm{~T}+0.00043$ $\bullet \mathrm{T}^{2}-0.18803^{*} \mathrm{~T} * \mathrm{P}$

d)
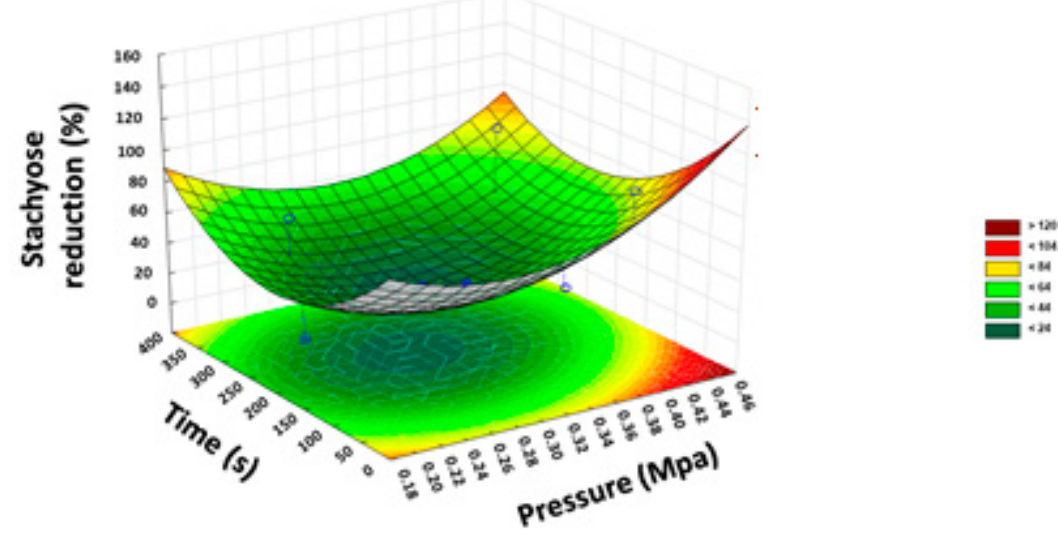

Stachyose reduction $(\%)=213.19943-1004.39673 * \mathrm{P}+1828.27101^{*} \mathrm{P}^{2}-0.39109 * \mathrm{~T}+$ $0.00113 \mathrm{~T}^{2}-0.36664^{*} \mathrm{~T} * \mathrm{P}$

Figure 3. Surface response plot of NNFs reduction by DIC treatment. (a) Total phenolics, (b) Condensed tannins, (c) $\mathrm{IP}_{6}$, (d) Stachyose. $\mathrm{P}=$ pressure; $\mathrm{T}=$ Time.

In the study of Pedrosa et al. [11], the optimal DIC conditions to achieve a global reduction of NNFs of different legumes were $0.6 \mathrm{MPa}$ and $60 \mathrm{~s}$. In the specific case of oligosaccharides, DIC reduced the raffinose concentration for all legumes in 5\%,7\%, 9\%, 18\%, and $24 \%$ for soybeans, lupins, roasted peanuts, chickpea, and lentils respectively. Not the same behavior for stachyose, where for roasted peanuts, lupin, and chickpea DIC allowed a concentration reduction of $11 \%, 13 \%$, and $14 \%$ respectively; however, for lentils and soybean, the concentration of this sugar was increased on $12 \%$ and 3\% respectively. By comparing to our results, it can be observed that there is a considerable difference between the oligosaccharides reduction of those legumes and vetches (77\% for raffinose and $92 \%$ for stachyose). This difference could be linked to the particle size of the raw material and the DIC treatment time ( $1 \mathrm{~min}$ vs. $5 \mathrm{~min}$ ). Whole meals of legumes were submitted to DIC treatment in the study previously described, however, in this work we used vetches flour. Besides, the longer treatment time could allow the increase of sugar leaching on the steam.

According to Haddad and Allaf [32], their results showed that their applied operating parameters, DIC treatment could achieve different reduction ratio of NNF, being remarked that under high pressure 
treatment $(0.70 \mathrm{MPa})$ and short time $(60 \mathrm{~s})$ the NNF of soybeans and lupins seeds (L. albus and L. mutabilis) could be reduced to $94 \%, 16 \%$, and $19 \%$ respectively

Furthermore, respect to $\mathrm{IP}_{6}$ content, the study of Pedrosa et al. [11] showed that DIC treatment allowed its reduction for all legumes: lupin $(91 \%)$, lentil (51\%), chickpea (45\%), soybean, and roasted peanut (34\%). By comparing to our results, it could be observed that according to the DIC treatment conditions, $\mathrm{IP}_{6}$ reduction could vary from $12 \%$ to $92 \%$. $\mathrm{IP}_{6}$ reduction of vetches could be linked to the thermal degradation of these molecules, the formation of insoluble complexes and the changes in their chemical reactivity during the DIC treatment [40].

On the other hand, according to Yağcl and Evci [41], the DIC process increased the total phenolic content of chickpea varying according to the treatment conditions. As higher the processing pressure and treatment time, the polyphenols content was increased, achieving the highest content (twofold respect to the control) at $0.5 \mathrm{MPa}$ and $10 \mathrm{~min}$. By comparing to our results, it could be observed an opposite behavior; this difference could be linked to the intrinsic chemical composition of each legume and their initial moisture content (30\% in chickpea and $15 \%$ in vetches). Depending on the achieved temperature during DIC treatment, and the initial water content of food polymers, the rate of vapor generated by auto vaporization during the DIC treatment starts acting as a swelling gas on the concerned polymer. Then according to the initial moisture content, DIC treatment can generate structural expansion, which increases the extraction of biomolecules, such as polyphenols and tannins [42]. Moreover, in this study, phenols reduction could be also linked to its decarboxylation during heating of DIC treatment. The reduction percentage of phenolics compounds achieved by DIC treatments, are accordingly to those reported by $\mathrm{Xu}$ and Chang [29], where not only a reduction of phenolic compounds was reported, but an increase of antioxidant activity in steamed legumes. Since DIC is a HTST treatment that consist in high pressure steam, it could be that vetches show improved antioxidant activity after DIC treatment.

\subsubsection{Effect of Cooking on NNF of Vetches}

The effect of cooking on the NNF of vetches respect to RM is shown in Table 4. The cooking time of $45 \mathrm{~min}$ showed the lowest raffinose $(91.3 \%)$, stachyose $(81.7 \%)$, and phytates $(87.78 \%)$ reductions. Phytates reduction showed no significative difference in times above $45 \mathrm{~min}$. The reduction of phytic acid is probably due to hydrolysis during cooking and also caused by the formation of insoluble complexes [43].

Table 4. Effect of cooking over total phenolics, condensed tannins, and flavonoids.

\begin{tabular}{ccccccc}
\hline Sample & $\begin{array}{c}\text { Total Phenolics } \\
\text { Reduction } \\
\mathbf{( \% )}\end{array}$ & $\begin{array}{c}\text { Tannins } \\
\text { Reduction } \\
\mathbf{( \% )}\end{array}$ & $\begin{array}{c}\text { Flavonoids } \\
\text { Reduction } \\
\mathbf{( \% )}\end{array}$ & $\begin{array}{c}\text { Phytates } \\
\text { Reduction } \\
\mathbf{( \% )}\end{array}$ & $\begin{array}{c}\text { Raffinose } \\
\text { Reduction } \\
\mathbf{( \% )}\end{array}$ & $\begin{array}{c}\text { Stachyose } \\
\text { Reduction } \\
\mathbf{( \% )}\end{array}$ \\
\hline C45 & $30.8^{\mathrm{a}}$ & $13.2^{\mathrm{a}}$ & $29.4^{\mathrm{b}}$ & $87.8^{\mathrm{b}}$ & $91.3^{\mathrm{b}}$ & $87.7^{\mathrm{b}}$ \\
C60 & $39.5^{\mathrm{a}}$ & $17.7^{\mathrm{a}}$ & $51.2^{\mathrm{a}}$ & $95.9^{\mathrm{a}}$ & $93.8^{\mathrm{a}}$ & $95.8^{\mathrm{a}}$ \\
C90 & $-10.9^{\mathrm{b}}$ & $18.5^{\mathrm{a}}$ & $48.8^{\mathrm{a}}$ & $95.6^{\mathrm{a}}$ & $94.2^{\mathrm{a}}$ & $95.7^{\mathrm{a}}$ \\
C120 & $9^{\mathrm{c}}$ & $20.5^{\mathrm{a}}$ & $47.1^{\mathrm{a}}$ & $95.3^{\mathrm{a}}$ & $96.1^{\mathrm{c}}$ & $95.0^{\mathrm{c}}$ \\
\hline
\end{tabular}

Values are expressed as means of three replicates. Letters in the same column indicate significative differences.

Raffinose showed higher reduction after 120 min of cooking time (96\%), while stachyose showed their highest reduction (95\%) with no significative differences among 60-90 min. Ibrahim et al. [22], reported reductions around $100 \%$ of raffinose and stachyose of chickpea soaked in $0.03 \%$ sodium bicarbonate solution $(16 \mathrm{~h})$ followed by two heating methods: cooking at $100{ }^{\circ} \mathrm{C}$ for $45 \mathrm{~min}$ and pressure cooked $\left(1 \mathrm{~kg} / \mathrm{cm}^{2}\right)$ at $120^{\circ} \mathrm{C}$ during $20 \mathrm{~min}$. Since oligosaccharides are relatively heated stable, their reduction is mainly attributed to their diffusion into the water during soaking and cooking $[44,45]$. Moreover, according to the solubility and diffusion rate of each oligosaccharide, sugar losses could be enhanced by increasing the soaking and cooking time and employing different soaking media [45]. 
The highest flavonoids reduction was found at $60 \mathrm{~min}$ of cooking (51.17\%), with no significant difference among other treatments with high flavonoids reduction. In the case of condensed tannins, no significant differences were found among the four different cooking treatments, showing reductions from $13 \%$ up to $20 \%$. Total phenolics reduction showed no significant differences between C45 and C60; moreover, after 60 min of cooking the highest reduction of total phenolics was achieved $(39.52 \%)$. The reductions are in agreement with those reported for colored beans and chickpeas [30]. Khandelwal et al. [23] also reported reductions of total polyphenol and tannins of four legumes cooked until softness ( $\left.121^{\circ} \mathrm{C}, 15 \mathrm{psi}\right)$ : lentil (41\% and 36\%), green gram (41\% and $\left.45 \%\right)$, Bengal gram (35\% and $28 \%$ ), and red gram (45\% and 34\%), respectively. Similar results are reported by Xu and Chang [29], which showed that boiling legumes reduced phenolic compounds up to $50 \%$, however, for steamed legumes, the reductions were lower (up to $28 \%$ ), but they also reported an increase of the antioxidant activity due to polyphenols. Then, the reduction of polyphenols and tannins could be attributed to both, its diffusion to the water during soaking and cooking [46], and the destruction or transformation of its chemical structures during heat treatment [47].

\subsubsection{Effect of Germination on NNF of Vetches}

The effect of germination on the NNF of vetches respect to RM is shown in Table 5. As can be observed, germination boosted the reduction of raffinose $(96 \%)$, stachyose $(95 \%)$ and $\mathrm{IP}_{6}(95 \%)$, however, not the same behavior was found for total phenolics, flavonoids, and condensed tannins which increased its concentration on $28 \%, 27 \%$, and $4 \%$ respectively.

Table 5. Effect of germination on NNF.

\begin{tabular}{ccc}
\hline NNF & Reduction (\%) & Increase (\%) \\
\hline Total phenolics & - & $28.6 \pm 3.1$ \\
Flavonoids & - & $27.2 \pm 2.8$ \\
Condensed Tannins & - & $4.4 \pm 0.0$ \\
IP6 & $95.8 \pm 0.2$ & - \\
Raffinose & $96.1 \pm 0.6$ & - \\
Stachyose & $95.9 \pm 0.0$ & - \\
\hline
\end{tabular}

Values are expressed as means of three replicates $\pm \mathrm{SD}$.

Respect to oligosaccharides, similar results were founding on cowpeas, where $85 \%$ and $95 \%$ stachyose reduction occurred after germination at $35{ }^{\circ} \mathrm{C}$ for $48 \mathrm{~h}$ and $72 \mathrm{~h}$ respectively; moreover, after $48 \mathrm{~h}$ of germination at $30^{\circ} \mathrm{C}$ stachyose was disappeared [48]. According to Martín-Cabrejas, et al. [49] germination increase the activity of the enzyme $\alpha$-galactosidase, which hydrolyzes the $\alpha$-1-6-galactosidic linkages, thereby causing an efficient reduction of the $\alpha$-galactosides content.

On the other hand, phytic acid reduction on germinated vetches could be linked to an increase in phytase activities. In fact, this enzyme makes the phytates soluble to support seedling growth [50]. Similar results were found on chickpea after $48 \mathrm{~h}$ of germination, where phytic acid content was reduced on 59\% [51]. Our results are in agreement with those reported by Mohammed, et al. [52], where the germination significantly decreased the content of phytic acid of lupin (Lupinus albus) due to phytase activity, that increases over time.

Respect to total phenolics, flavonoids, and condensed tannins content, most studies found that germinated seeds presented a higher content of these molecules than raw seed. For example, Dicko, et al. [53] reported an increase of total phenolics and flavonoids in different sorghum varieties, due to the activity of enzymes stimulated during germination. $\mathrm{Xu}$, et al. [54] found a significant increase in the total soluble phenolic compounds (free + soluble bound phenolics) of germinated chickpea and yellow pea. Lin and Lai [55] reported that after long-term germination, the contents of bioactive compounds (total phenolics and flavonoids) significantly increased in black soybeans. According to López-Martínez et al. [37], glucose is the original precursor for the synthesis of phenolic compounds, and several crucial molecular signaling pathways, including hydrolyzable tannin pathway. 
Duenas, et al. [56] also reported an increase of total phenolics and flavonoids, on the germination of lupin seeds, however, the authors reported an increase of $84 \%$ of phenolics compounds, after 9 days of germination. Then in function of the kind of legume and the germination process (seeds water content, temperature, lightness or darkness, days of germination, oxygen concentration, among others) the final content of polyphenols on germinated legumes could varied significantly. Although germination significantly reduce $\mathrm{IP}_{6}$, raffinose, and stachyose within our germination time, these reductions can be improved if germination is extended to 9 days or more. This also could lead to higher increase of total phenolics, flavonoids, and tannins, that could improve some beneficial aspects to human health, such as antioxidant activity.

\subsection{Principal Component Analysis}

To reduce the number of response variables, a principal component analysis (PCA) was done. Six components where obtained, where principal component 1 (PC1) and principal component 2 (PC2) described $85 \%$ of the variability. Figure 4 shows the classification of the three different treatments (cooking, germination, and DIC) applied to vetches in function to PC1 and PC2. Figure 4a shows that $\mathrm{IP}_{6}$, stachyose, and raffinose reduction have a higher contribution to $\mathrm{PC} 1$ construction, while total phenolics, condensed tannins, and flavonoids have a higher contribution to PC2. The resultant biplot (Figure $4 \mathrm{~b}$ ) shows three different groups respect to PC1. The first is formed by cooking treatments $\left(\mathrm{C} 45, \mathrm{C} 60, \mathrm{C} 90\right.$, and C120) and DIC treatments (D5 and D6) characterized by the highest $\mathrm{IP}_{6}$, stachyose, and raffinose reduction. Although D5 and D6 were performed at the same pressure (0.41 MPa), they differ in process time ( 312 and $78 \mathrm{~s}$, respectively). A second group is only formed by D8 and D9, which is characterized by sharing the same pressure tested $(0.24 \mathrm{MPa})$. These treatments have shown intermediate values of NNF reductions. The third group is formed by D1, D2, D4, D7, D10, D11, D12, and D13, with the lowest NNF reduction with different pressure-time combinations. Germination showed high reduction percentages on $\mathrm{IP}_{6}$, raffinose, and stachyose, but an increase total phenolics, condensed tannins, and flavonoid content.

Since our investigation tried to reduce NNF content on vetches, germination may not be a suitable method to reduce all NNF, however, germination could benefit human health due to the increase of phenolic compounds. On the other hand, D3 has the lowest reduction of $\mathrm{IP}_{6}$ and raffinose reduction, despite having high flavonoid reduction among DIC treatments, however, $\mathrm{IP}_{6}$ have been demonstrated beneficial effects to human health such as reduced bioavailability of heavy metals (lead and cadmium), antioxidant activity, among others [57]. 

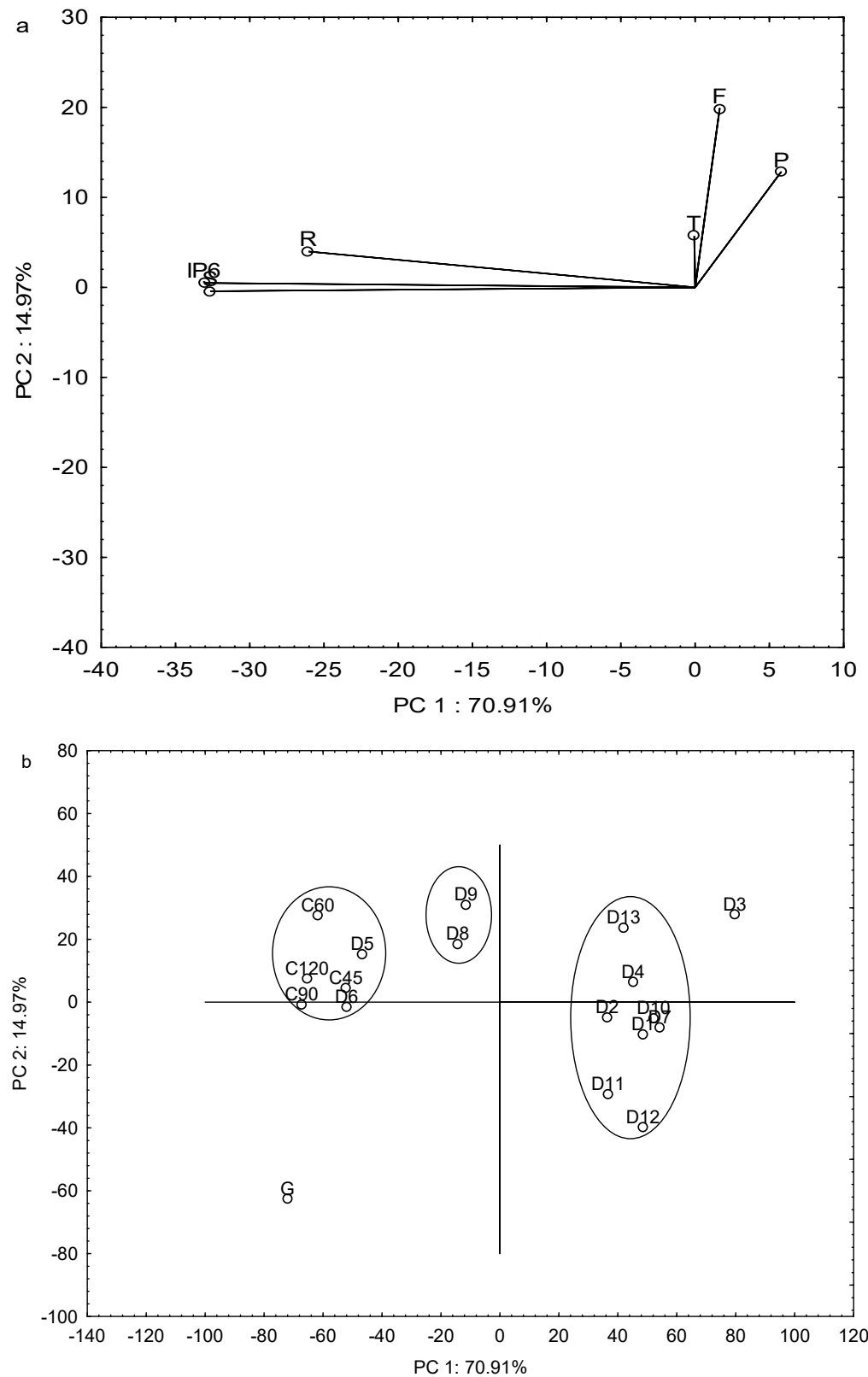

Figure 4. Principal component analysis. (a) Projection of the variables on the factor-plane, (b) Projection of the cases on the factor-plane. $\mathrm{P}=$ Total phenolics, $\mathrm{T}=$ condensed tannins, $\mathrm{F}=$ flavonoids, $\mathrm{R}=$ raffinose, $\mathrm{S}=$ stachyose, $\mathrm{G}=$ germination, $\mathrm{C}=$ cooking, $\mathrm{D}=\mathrm{DIC}$ treatments.

\section{Materials and Methods}

\subsection{Seeds}

Common vetch (Vicia sativa) was kindly provided by Campo Agropecuario Experimental of Tecnologico de Monterrey (Queretaro, Mexico). Seeds were kept under dark and dry conditions until their use.

\section{Chemical Proximate Analysis}

Moisture (925.10), ashes (942.05), total nitrogen (920.87), ethereal extract (945.39), and crude fiber (962.60E) were carried out in non-treated vetch flour according to AOAC official methods [58]. Results were expressed as a percentage (wet basis). 


\subsection{Vetches Treatments}

Before any treatment, vetches were divided into four groups of samples: instant controlled pressure drop, cooking, germination and raw material.

\subsubsection{Instant Controlled Pressure Drop}

An Instant Controlled Pressure Drop treatment (DIC) was carried out according to Pedrosa et al. [11] with slight modifications. One hunderd g of non-treated grounded seeds were put into the LABIC 0.1 DIC equipment (ABCAR-DIC Process, La Rochelle, France) following a central composite rotatable experimental design [59]. Saturated steam pressure $(\mathrm{P})$ and thermal treatment time $(t)$ were the independent variables. The design yielded 13 experiments with four $\left(2^{2}\right)$ factorial points, four-star points $(-\alpha,-1,0,+1$ and $+\alpha)$ and five central points $(0,0)$. Pressure values ranged from 0.20 to $0.45 \mathrm{MPa}$ and treatment time from 30 to $360 \mathrm{~s}$. Run experimental values are shown in Table 6 . After DIC treatment, obtained flours were kept under dry conditions and darkness until their use.

Table 6. Vetch flour DIC processing conditions.

\begin{tabular}{ccc}
\hline Sample & Saturated Steam Pressure $\mathbf{( M P a )}$ & Treatment Time $(\mathbf{s})$ \\
\hline DIC1 & 0.33 & 195 \\
DIC2 & 0.45 & 195 \\
DIC3 & 0.33 & 360 \\
DIC4 & 0.33 & 195 \\
DIC5 & 0.41 & 312 \\
DIC6 & 0.41 & 78 \\
DIC7 & 0.33 & 195 \\
DIC8 & 0.24 & 78 \\
DIC9 & 0.24 & 312 \\
DIC10 & 0.33 & 195 \\
DIC11 & 0.20 & 195 \\
DIC12 & 0.33 & 30 \\
DIC13 & 0.33 & 195 \\
\hline
\end{tabular}

\subsubsection{Cooking Treatment}

Cooking was carried out according to de Almeida Costa et al. [39] and Barampama and Simard [60] with slight modifications. First, vetch seeds were soaked in sterile water during $12 \mathrm{~h}(10 \% \mathrm{w} / \mathrm{v})$, at $25^{\circ} \mathrm{C}$. Then, soaking water was discarded and replaced with fresh water. Seeds were cooked with boiling water $(10 \% w / v)$ for 45, 60, 90, and $120 \mathrm{~min}$, (C45, C60, C90, and C120, respectively). After cooking, seeds were dried at $45{ }^{\circ} \mathrm{C}$ until a final moisture content of $15-20 \%$ dry basis. Finally, all samples were ground and passed through 60 mesh sieve.

\subsubsection{Germination}

Germination was carried out according to de Souza Rocha, et al. [61]. Seeds were rinsed with sterile water and kept at $25^{\circ} \mathrm{C}$ under light/dark cycles $(12 \mathrm{~h})$. Once cotyledons sprouted about $10 \mathrm{~cm}$ ( 5 to 6 days), germinated seeds were also dried at $45^{\circ} \mathrm{C}$ until a final moisture content of $15-20 \%$. Dried samples were milled to pass 60 mesh sieves.

\subsection{Non-Nutritional Factors Evaluation}

\subsubsection{Methanolic Extracts Preparation}

$1 \mathrm{~g}$ of grounded seeds (treated and not treated) were extracted with $20 \mathrm{~mL}$ of methanol with $\mathrm{HCl}$ $(1 \%)$ in agitation $(130 \mathrm{rpm})$ during $2 \mathrm{~h}$ under dark conditions at $25^{\circ} \mathrm{C}$. Methanolic extracts were filtered and stored in the dark at $-20^{\circ} \mathrm{C}$ until analysis [62]. 


\subsubsection{Total Phenolics Quantification}

Total phenolics were estimated according to Singleton et al. [63] with slight modifications. $150 \mu \mathrm{L}$ of water was added to $20 \mu \mathrm{L}$ of methanolic extract and oxidized with $50 \mu \mathrm{L}$ of Folin-Ciocalteu reagent $(0.5 \mathrm{~N})$, then, neutralized with $50 \mu \mathrm{L}$ of sodium carbonate solution $(20 \% w / v)$. The mixture was incubated for $2 \mathrm{~h}$ at $25^{\circ} \mathrm{C}$. After the incubation time, absorbance was measured at $760 \mathrm{~nm}$ using an xMark Microplate Spectrophotometer (Bio-Rad, Hercules, CA, USA). A standard curve of gallic acid (0 to $300 \mu \mathrm{M}$ ) was done. Results were expressed as mg of gallic acid equivalent per $\mathrm{g}$ of vetch flour dry weight. Samples were analyzed in triplicates.

\subsubsection{Flavonoids Quantification}

Quantitative determination of flavonoid content was performed by mixing $50 \mu \mathrm{l}$ of a methanolic extract with $180 \mu \mathrm{L}$ of distilled water and $20 \mu \mathrm{L}$ of 2-aminoethyldiphenyl borate solution (10 g/L) [64]. After $10 \mathrm{~min}$, absorbance was measured at $404 \mathrm{~nm}$ using a 96 micro well flat-bottom plate using an xMark Microplate Spectrophotometer (Bio-Rad, Hercules, CA, USA). Extracts absorbance was compared with a standard curve of rutin $(0$ to $0.05 \mathrm{~g} / \mathrm{mL})$. Flavonoid content was expressed as $\mathrm{mg}$ rutin equivalent per $\mathrm{g}$ of vetch flour dry weight. Samples were analyzed in triplicate.

\subsubsection{Tannins Quantification}

Tannins were quantified by spectrophotometric vanillin assay $[65,66]$ adapted to microplates. $20 \mu \mathrm{L}$ extract were mixed with $100 \mu \mathrm{L}$ vanillin reagent (vanillin $1 \%$ plus $8 \% \mathrm{HCl} \mathrm{1:1} v / v$ ). The mixture was incubated at $30{ }^{\circ} \mathrm{C}$ for $30 \mathrm{~min}$. Absorbance was measured at $500 \mathrm{~nm}$ (xMark Microplate Spectrophotometer). Results were expressed as mg equivalent of catechin (compared with the standard curve from 0.25 to $1 \mathrm{mg} / \mathrm{mL}$ ) per g of vetch flour dry weight. Samples were analyzed in triplicate.

\subsubsection{Oligosaccharides Quantification}

$5 \mathrm{~mL}$ of ethanol $(50 \% \mathrm{v} / \mathrm{v})$ was added to $0.5 \mathrm{~g}$ of vetch flour and was homogenized for $1 \mathrm{~min}$ in Ultra-turrax (IKA Works Inc., Wilmington, DE, USA). Afterward, centrifugation (HERMLE Z383K, Wehingen, Germany) was carried out at $2817 \mathrm{~g}\left(4^{\circ} \mathrm{C}, 10 \mathrm{~min}\right)$ recovering supernatant. This process was carried out three times. The supernatants were collected and passed through a solid phase extraction (SPE) SampliQ C-18 column (200 mg bonded silica, 3 mL, $45 \mu \mathrm{m}, 1200$ series, Agilent Technologies, Santa Clara, CA, USA) previously activated with $3 \mathrm{~mL}$ distilled water and $3 \mathrm{~mL}$ of methanol. Oligosaccharides collected were vacuum-dried in a rotary evaporator and resuspended with $1 \mathrm{~mL}$ of distilled water, then filtered through $0.45 \mu \mathrm{m}$ membrane [67]. Extracts were analyzed with a liquid chromatographer (Agilent Technologies 1200 series) with a refraction index detector. A $20 \mu \mathrm{L}$ injection of oligosaccharides was passed through a Zorbax Carbohydrate column $(4.6 \times 150 \mathrm{~mm}, 3.5 \mu \mathrm{m}$, Agilent Technologies). The mobile phase contained acetonitrile-water (60:40 v/v) and set to a flow rate of $1 \mathrm{~mL} / \mathrm{min}$. The concentration was calculated using a calibration curve of raffinose and stachyose $(0-2 \mathrm{mg} / \mathrm{mL})$ [68]. Results were expressed as $\mathrm{mg}$ per $\mathrm{g}$ of vetch flour dry weight.

\subsubsection{Phytates Quantification}

For phytates determination, $10 \mathrm{~mL}$ of $\mathrm{HCl} 0.5 \mathrm{M}$ was added to $0.5 \mathrm{~g}$ of vetch flour and homogenized in Ultra-Turrax (IKA Works Inc.) during $1 \mathrm{~min}$; then, mixtures were centrifugated at $2817 \mathrm{~g}\left(4^{\circ} \mathrm{C}\right.$, $10 \mathrm{~min}$ ) recovering supernatant. This procedure was done three times. The total supernatants collected were passed through a strong anionic exchange (SAX) column (100 mg bonded silica, $1 \mathrm{~mL}, 45 \mu \mathrm{m}$ ) (Agilent Technologies 1200 series) activated with $5 \mathrm{~mL}$ methanol, then $5 \mathrm{~mL} \mathrm{HCl} 0.5 \mathrm{M}$. The filtrate was discarded, and the phytates retained in column were eluted with $2 \mathrm{~mL} \mathrm{HCl} 2 \mathrm{M}$, vacuum-dried in a rotary evaporator and resuspended with $2 \mathrm{~mL}$ of a solution containing $51.5 \mathrm{~mL}$ methanol, $48.5 \mathrm{~mL}$ distilled water, $1.6 \mathrm{~mL}$ of tert-butyl ammonium hydroxide (TBNOH) (Fluka Analytical, Charlotte, NC, USA), $0.2 \mathrm{~mL}$ sulfuric acid $5 \mathrm{M}$ and $1 \mathrm{~mL}$ formic acid (91\%) and filtered through a $0.45 \mu \mathrm{m}$ membrane 
prior to vial incorporation. A $20 \mu \mathrm{L}$ injection of the filtered solution was passed through a reverse phase (Zorbax Eclipse XDB C-18 column, $4.6 \times 150 \mathrm{~mm}, 5 \mu \mathrm{m}$ ) for HPLC analysis using a diode array detector. The mobile phase was the same solution used to resuspend phytates, with a flow rate of $1 \mathrm{~mL} / \mathrm{min}$. The identification of phytic acid was done by comparing the retention time of sodium phytate $\left(\mathrm{IP}_{6}\right)$ standard [69]. IP6 was expressed as phytic acid mg per $\mathrm{g}$ of vetch flour dry weight.

\subsubsection{Statistical Analysis}

Statistical Analysis was performed using the Statistica software (TIBCO Software Inc., Palo Alto, CA, USA). For each treatment analysis of variance (ANOVA) and multiple comparisons by Tukey's honest significant test $(\alpha<0.05)$ was applied to evaluate any significant difference. In the case of the experimental design of DIC treatment, statistical analysis was also performed by the surface response methodology. Finally, for all the responses, principal component analysis (PCA) was also performed to visualize the distance and relatedness between treatments.

\section{Conclusions}

To improve the nutritional profiles of pulses, this study focused on the effect of Instant Controlled Pressure Drop technology (DIC), cooking and germination on the reduction of $\mathrm{IP}_{6}$, raffinose, stachyose, total phenolics, flavonoids and condensed tannins of vetches. By cooking, it was possible to reduce significantly the NNFs of vetches, however long thermal treatments could cause adverse effects on nutrients such as lipids degradation or vitamin loss. Germination also removed $\mathrm{IP}_{6}$ and oligosaccharides (raffinose and stachyose) well and, it also may lead to an increase of total phenolics, flavonoids, and condensed tannins. This could be beneficial since total phenolics, flavonoids, and condensed tannins have been demonstrated to increase some important bioactivities for human health, for instance, antioxidant activity. Moreover, according to the literature, the selected operation conditions during germination directly impact the NNFs content. Therefore, further studies are needed to evaluate the effect of the main variables during germination such as seed water content, lightness or darkness, temperature, and days of germination. The instant controlled pressure drop (DIC) method was an effective technology to reduce NNFs of vetches in only $5 \mathrm{~min}$, getting similar results to cooking, which exerted the highest reductions. Further studies must be performed to evaluate the effect of the initial moisture content of seeds, the particle size, and the possibility to couple DIC process in tandem with soaking and germination, as well as other novel technologies such as ultrasound and microwaves to achieve optimal NNFs levels. Moreover DIC can be easily adapted at an industrial scale. Nevertheless, in all the cases, more studies are needed to evaluate the effect of cooking, germination and DIC treatment on antinutritional factors with protein nature, and the effect of these treatments over the bioactive compounds present in vetches.

Author Contributions: Conceptualization, A.C.-M.; Data curation, C.T.-P.; Formal analysis, C.T.-P.; Investigation, A.I.H.-A.; Methodology, A.I.H.-A. and A.S.M.-A.; Supervision, C.T.-P. and A.S.M.-A.; Writing-original draft, A.I.H.-A.; Writing-review \& editing, C.T.-P. and A.C.-M. All authors have read and agreed to the published version of the manuscript.

Funding: This research received no external funding.

Acknowledgments: Author Hernandez-Aguirre A.I. was supported by Consejo Nacional de Ciencia y Tecnología (CONACyT) through s scholarship (376098). We also thank Carl Heinz from Campo Agropecuario Experimental del Tecnologico de Monterrey for kindly providing vetch seeds for our research.

Conflicts of Interest: The authors declare no conflict of interest.

\section{References}

1. López-Barrios, L.; Gutiérrez-Uribe, J.A.; Serna-Saldívar, S.O. Bioactive Peptides and Hydrolysates from Pulses and their Potential Use as Functional Ingredients. J. Food Sci. 2014, 79, R273-R283. [CrossRef]

2. FAO. International Year of Legumes. Available online: http://www.fao.org/pulses-2016/en/ (accessed on 23 October 2017). 
3. Padhi, E.M.T.; Ramdath, D.D. A Review of the Relationship Between Pulse Consumption and Reduction of Cardiovascular Disease Risk Factors. J. Funct. Foods. 2017, 38, 635-643. [CrossRef]

4. Mathers, J.C. Pulses and Carcinogenesis: Potential for the Prevention of Colon, Breast and Other Cancers. Br. J. Nutr. 2007, 88, 273-279. [CrossRef]

5. Ramdath, D.; Renwick, S.; Duncan, A.M. The Role of Pulses in the Dietary Management of Diabetes. Can. J. Diabetes 2016, 40, 355-363. [CrossRef]

6. Jayalath, V.H.; de Souza, R.J.; Sievenpiper, J.L.; Ha, V.; Chiavaroli, L.; Mirrahimi, A.; Di Buono, M.; Bernstein, A.M.; Leiter, L.A.; Kris-Etherton, P.M.; et al. Effect of Dietary Pulses on Blood Pressure: A Systematic Review and Meta-analysis of Controlled Feeding Trials. Am. J. Hypertens. 2014, 27, 56-64. [CrossRef]

7. FAOSTAT. Food and Agriculture Data. Available online: http://www.fao.org/faostat/en/\#data/QC (accessed on 12 January 2018).

8. Ribeiro, A.C.; Teixeira, A.R.; Ferreira, R.B. Characterization of Globulins from Common Vetch (Vicia Sativa L.). J. Agric. Food Chem. 2004, 52, 4913-4920. [CrossRef]

9. Soetan, K.; Oyewole, O. The Need for Adequate Processing to Reduce the Anti- Nutritional Factors in Plants Used as Human Foods and Animal Feeds: A review. Afr. J. Food Sci. 2009, 3, 223-232.

10. Gupta, R.K.; Gangoliya, S.S.; Singh, N.K.J. Reduction of Phytic Acid and Enhancement of Bioavailable Micronutrients in Food Grains. J. Food Sci. Technol. 2015, 52, 676-684. [CrossRef] [PubMed]

11. Pedrosa, M.M.; Cuadrado, C.; Burbano, C.; Allaf, K.; Haddad, J.; Gelencsér, E.; Takács, K.; Guillamón, E.; Muzquiz, M. Effect of Instant Controlled Pressure Drop on the Oligosaccharides, Inositol Phosphates, Trypsin Inhibitors and Lectins Contents of Different Legumes. Food Chem. 2012, 131, 862-868. [CrossRef]

12. Pugalenthi, M.; Siddhuraju, P.; Vadivel, V. Effect of Soaking Followed by Cooking and the Addition of $\alpha$-Galactosidase on Oligosaccharides Levels in Different Canavalia Accessions. J. Food Compos. Anal. 2006, 19, 512-517. [CrossRef]

13. Suneja, Y.; Kaur, S.; Gupta, A.K.; Kaur, N. Levels of Nutritional Constituents and Antinutritional Factors in Black Gram (Vigna Mungo L. Hepper). Food Res. Int. 2011, 44, 621-628. [CrossRef]

14. Roberfroid, M. Health Benefits of Non-Digestible Oligosaccharides. In Dietary Fiber in Health and Disease; Springer: Basel, Switzwerland, 1997; pp. 211-219.

15. Thompson, L.U. Potential Health Benefits and Problems Associated with Antinutrients in Foods. Food Res. Int. 1993, 26, 131-149. [CrossRef]

16. Gemede, H.F. Potential Health Benefits and Adverse Effects Associated with Phytate in Foods: A Review. Glob. J. Med. Res. 2014, 27, 2224-6088.

17. Muzquiz, M.; Wood, J.; Yadav, S.; Redden, B.; Chen, W.; Sharma, B. Chickpea Breeding and Management; CABI International: Wallingford, UK, 2007.

18. Cuadrado, C.; Takacs, K.; Szabó, E.; Pedrosa, M. Non-nutritional Factors: Lectins, Phytic Acid, Proteases Inhibitors, Allergens. In Legumes; Royal Chemistry Society: London, UK, 2018; pp. 152-176.

19. Champ, M.M.-J. Non-Nutrient Bioactive Substances of Pulses. Br. J. Nutr. 2002, 88, 307-319. [CrossRef]

20. Campos-Vega, R.; Loarca-Piña, G.; Oomah, B.D. Minor components of pulses and their potential impact on human health. Food Res. Int. 2010, 43, 461-482. [CrossRef]

21. Avilés-Gaxiola, S.; Chuck-Hernández, C.; Serna Saldívar, S.O. Inactivation Methods of Trypsin Inhibitor in Legumes: A Review. Concise. Rev. Hypotheses. Food Sci. 2017, 83, 17-29. [CrossRef]

22. Ibrahim, S.; Habiba, R.; Shatta, A.; Embaby, H. Effect of Soaking, Germination, Cooking and Fermentation on Antinutritional Factors in Cowpeas. Mol. Nutr. Food Res. 2002, 46, 92-95. [CrossRef]

23. Khandelwal, S.; Udipi, S.A.; Ghugre, P. Polyphenols and Tannins in Indian Pulses: Effect of Soaking, Germination and Pressure Cooking. Food Res. Int. 2010, 43, 526-530. [CrossRef]

24. Vidal-Valverde, C.; Frias, J.; Estrella, I.; Gorospe, M.J.; Ruiz, R.; Bacon, J. Effect of Processing on Some Antinutritional Factors of Lentils. J. Agric. Food Chem. 1994, 42, 2291-2295. [CrossRef]

25. Sadeghi, G.; Pourreza, J.; Samei, A.; Rahmani, H. Chemical Composition and Some Anti-Nutrient Content of Raw and Processed Bitter Vetch (Vicia ervilia) Seed for Use as Feeding Stuff in Poultry Diet. Trop. Anim. Health. Prod. 2009, 41, 85-93. [CrossRef] 
26. Silva, H.; Braga, G. Effect of Soaking and Cooking on the Oligosaccharide Content of Dry Beans (Phaseolus vulgaris, L.). J. Food Sci. 1982, 47, 924-925. [CrossRef]

27. Kon, S. Effect of Soaking Temperature on Cooking and Nutritional Quality of Beans. J. Food Sci. 1979, 44, 1329-1335. [CrossRef]

28. Walker, A.F.; Kochhar, N. Effect of Processing Including Domestic Cooking on Nutritional Quality of Legumes. Proc. Nutr. Soc. 1982, 41, 41-51. [CrossRef]

29. Xu, B.; Chang, S.K. Effect of Soaking, Boiling, and Steaming on Total Phenolic Contentand Antioxidant Activities of Cool Season Food Legumes. Food Chem. 2008, 110, 1-13. [CrossRef]

30. Wang, N.; Hatcher, D.; Tyler, R.; Toews, R.; Gawalko, E. Effect of Cooking on the Composition of Beans (Phaseolus vulgaris L.) and Chickpeas (Cicer arietinum L.). Food Res. Int. 2010, 43, 589-594. [CrossRef]

31. Mounir, S.; Allaf, K. Three-Stage Spray Drying: New Process Involving Instant Controlled Pressure Drop. Dry. Technol. 2008, 26, 452-463. [CrossRef]

32. Haddad, J.; Allaf, K. A Study of the Impact of Instantaneous Controlled Pressure Drop on the Trypsin Inhibitors of Soybean. J. Food Eng. 2007, 79, 353-357. [CrossRef]

33. Jiménez Martínez, C.; Cardador Martínez, A.; Martinez Ayala, A.; Muzquiz, M.; Martin Pedrosa, M.; Dávila-Ortiz, G. Changes in Protein, Nonnutritional Factors, and Antioxidant Capacity During Germination of L. Campestris seeds. Int. J. Agron. 2012, 2012. [CrossRef]

34. Singh, P.; Gautam, A.; Panwar, H.; Singh, D.; Srivastava, N.; Bhagyawant, S.; Upadhayay, H. Effects of Germination on Antioxidant and Anti Nutritional Factors of Commonly Used Pulses. Int. J. Res. Chem. Environ. 2014, 4, 100-104.

35. Savelkoul, F.H.M.G.; Van Der Poel, A.F.B.; Tamminga, S. The Presence and Inactivation of Trypsin Inhibitors, Tannins, Lectins and Amylase Inhibitors in Legume Seeds During Germination. A review. Plant. Foods. Hum. Nutr. 1992, 42, 71-85. [CrossRef]

36. Sampath, S.; Rao, M.T.; Reddy, K.K.; Arun, K.; Reddy, P. Effect of Germination on Oligosaccharides in Cereals and Pulses. J. Food Sci. Technol-Mysore. 2008, 45, 196-198.

37. López-Martínez, L.X.; Leyva-López, N.; Gutiérrez-Grijalva, E.P.; Heredia, J.B. Effect of Cooking and Germination on Bioactive Compounds in Pulses and their Health Benefits. J. Funct. Foods 2017, 38, 624-634. [CrossRef]

38. Liang, J.; Han, B.-Z.; Nout, M.R.; Hamer, R.J. Effects of Soaking, Germination and Fermentation on Phytic Acid, Total and in Vitro Soluble Zinc in Brown Rice. Food Chem. 2008, 110, 821-828. [CrossRef]

39. de Almeida Costa, G.E.; da Silva Queiroz-Monici, K.; Reis, S.M.P.M.; de Oliveira, A.C. Chemical Composition, Dietary Fibre and Resistant Starch Contents of Raw and Cooked Pea, Common Bean, Chickpea and Lentil Legumes. Food Chem. 2006, 94, 327-330. [CrossRef]

40. Rathod, R.P.; Annapure, U.S. Effect of Extrusion Process on Antinutritional Factors and Protein and Starch Digestibility of Lentil Splits. LWT-Food Sci. Technol. 2016, 66, 114-123. [CrossRef]

41. Yağcl, S.; Evci, T. Effect of Instant Controlled Pressure Drop Process on Some Physicochemical and Nutritional Properties of Snacks Produced from Chickpea and Wheat. Int. J. Food Sci. Technol. 2015, 50, 1901-1910. [CrossRef]

42. Allaf, T.; Allaf, K. Instant Controlled Pressure Drop (D.I.C.) in Food Processing: From Fundamental to Industrial Applications; Springer: New York, NY, USA, 2013. [CrossRef]

43. Lee, H.; Ha, M.J.; Shahbaz, H.M.; Kim, J.U.; Jang, H.; Park, J. High Hydrostatic Pressure Treatment for Manufacturing of Red Bean Powder: A Comparison with the Thermal Treatment. J. Food Eng. 2018. [CrossRef]

44. Hefnawy, T. Effect of Processing Methods on Nutritional Composition and Anti-Nutritional Factors in Lentils (Lens Culinaris). Ann. Agric. Sci. 2011, 56, 57-61. [CrossRef]

45. Onyenekwe, P.; Njoku, G.; Ameh, D. Effect of Cowpea (Vigna unguiculata) Processing Methods On Flatus Causing Oligosaccharides. Nutr. Res. 2000, 20, 349-358. [CrossRef]

46. Kataria, A.; Chauhan, B.; Punia, D. Antinutrients and Protein Digestibility (in vitro) of Mungbean as Affected by Domestic Processing and Cooking. Food Chem. 1989, 32, 9-17. [CrossRef]

47. Burgos, V.E.; Binaghi, M.J.; de Ferrer, P.A.R.; Armada, M. Effect of Precooking on Antinutritional Factors and Mineral Bioaccessibility in Kiwicha Grains. J. Cereal. Sci. 2018, 80, 9-15. [CrossRef] 
48. Nnanna, I.A.; Phillips, R.D. Changes in Oligosaccharide Content, Enzyme Activities and Dry Matter during Controlled Germination of Cowpeas (Vigna Unguiculata). J. Food Sci. 1988, 53, 1782-1786. [CrossRef]

49. Martín-Cabrejas, M.A.; Díaz, M.F.; Aguilera, Y.; Benítez, V.; Mollá, E.; Esteban, R.M. Influence of Germination on the Soluble Carbohydrates and Dietary Fibre Fractions in Non-Conventional Legumes. Food Chem. 2008, 107, 1045-1052. [CrossRef]

50. Cominelli, E.; Confalonieri, M.; Carlessi, M.; Cortinovis, G.; Daminati, M.G.; Porch, T.G.; Losa, A.; Sparvoli, F. Phytic Acid Transport in Phaseolus Vulgaris: A New Low Phytic Acid Mutant in the PvMRP1 Gene and Study of the PvMRPs Promoters in Two Different Plant Systems. Plant. Sci. 2018, 270, 1-12. [CrossRef] [PubMed]

51. Khattak, A.B.; Zeb, A.; Bibi, N.; Khalil, S.A.; Khattak, M.S. Influence of Germination Techniques on Phytic Acid and Polyphenols Content of Chickpea (Cicer arietinum L.) Sprouts. Food Chem. 2007, 104, 1074-1079. [CrossRef]

52. Mohammed, M.A.; Mohamed, E.A.; Yagoub, A.E.A.; Mohamed, A.R.; Babiker, E.E. Effect of Processing Methods on Alkaloids, Phytate, Phenolics, Antioxidants Activity and Minerals of Newly Developed Lupin (Lupinus Albus L.) Cultivar. J. Food Process. Preserv. 2017, 41, e12960. [CrossRef]

53. Dicko, M.H.; Gruppen, H.; Traoré, A.S.; van Berkel, W.J.; Voragen, A.G. Evaluation of the Effect of Germination on Phenolic Compounds and Antioxidant Activities in Sorghum Varieties. J. Agric. Food Chem. 2005, 53, 2581-2588. [CrossRef]

54. Xu, M.; Jin, Z.; Peckrul, A.; Chen, B. Pulse Seed Germination Improves Antioxidative Activity of Phenolic Compounds in Stripped Soybean oil-in-water Emulsions. Food Chem. 2018, 250, 140-147. [CrossRef]

55. Lin, P.-Y.; Lai, H.-M. Bioactive Compounds in Legumes and Their Germinated Products. J. Agric. Food Chem. 2006, 54, 3807-3814. [CrossRef]

56. Duenas, M.; Hernández, T.; Estrella, I.; Fernández, D. Germination as a Process to Increase the Polyphenol Content and Antioxidant Activity of Lupin Seeds (Lupinus angustifolius L.). Food Chem. 2009, 117, 599-607. [CrossRef]

57. Muzquiz, M.; Varela, A.; Burbano, C.; Cuadrado, C.; Guillamón, E.; Pedrosa, M.M. Bioactive Compounds in Legumes: Pronutritive and Antinutritive Actions. Implications for Nutrition and Health. Phytochem. Rev. 2012, 11, 227-244. [CrossRef]

58. AOAC. Official Methods of Analysis of the AOAC, 15th ed.; Association of Official Analytical Chemists: Arlington, VA, USA, 1990.

59. Allaf, T.; Fine, F.; Tomao, V.; Nguyen, C.; Ginies, C.; Chemat, F. Impact of Instant Controlled Pressure Drop pre-treatment on solvent extraction of edible oil from rapeseed seeds. OCL 2014, 21, A301. [CrossRef]

60. Barampama, Z.; Simard, R.E. Effects of Soaking, Cooking and Fermentation on Composition, in-vitro Starch Digestibility and Nutritive Value of Common Beans. Plant. Foods Hum. Nutr. (Former. Qual. Plant.) 1995, 48, 349-365. [CrossRef]

61. de Souza Rocha, T.; Hernandez, L.M.R.; Mojica, L.; Johnson, M.H.; Chang, Y.K.; González de Mejía, E. Germination of Phaseolus Vulgaris and Alcalase Hydrolysis of its Proteins Produced Bioactive Peptides Capable of Improving Markers Related to type-2 Diabetes in Vitro. Food Res. Int. 2015, 76, 150-159. [CrossRef]

62. Cardador-Martínez, A.; Loarca-Piña, G.; Oomah, B.D. Antioxidant Activity in Common Beans (Phaseolus vulgaris L.). J. Agric. Food Chem. 2002, 50, 6975-6980. [CrossRef]

63. Singleton, V.L.; Orthofer, R.; Lamuela-Raventós, R.M. Analysis of Total Phenols and Other Oxidation Substrates and Antioxidants by Means of Folin-Ciocalteu Reagent. Method. Enzymol. 1999, 299, 152-178.

64. Oomah, B.D.; Cardador-Martínez, A.; Loarca-Piña, G. Phenolics and Antioxidative Activities in Common Beans (Phaseolus vulgaris L). J. Sci. Food Agric. 2005, 85, 935-942. [CrossRef]

65. Deshpande, S.; Cheryan, M. Evaluation of Vanillin Assay for Tannin Analysis of Dry Beans. J. Food Sci. 1985, 50, 905-910. [CrossRef]

66. Deshpande, S.; Cheryan, M. Determination of Phenolic Compounds of Dry Beans Using Vanillin, Redox and Precipitation Assays. J. Food Sci. 1987, 52, 332-334. [CrossRef]

67. Burbano, C.; Muzquiz, M.; Ayet, G.; Cuadrado, C.; Pedrosa, M.M. Evaluation of Antinutritional Factors of Selected. J. Sci. Food Agric. 1999, 79, 1468-1472. [CrossRef] 
68. Da Costa Leite, J.M.; Trugo, L.C.; Costa, L.S.M.; Quinteiro, L.M.C.; Barth, O.M.; Dutra, V.M.L.; De Maria, C.A.B. Determination of Oligosaccharides in Brazilian Honeys of Different Botanical Origin. Food Chem. 2000, 70, 93-98. [CrossRef]

69. Graf, E.; Dintzis, F.R. High-Performance Liquid Chromatographic Method for the Determination of Phytate. Anal. Biochem. 1982, 119, 413-417. [CrossRef]

Sample Availability: Samples are available from the authors.

(C) 2019 by the authors. Licensee MDPI, Basel, Switzerland. This article is an open access article distributed under the terms and conditions of the Creative Commons Attribution (CC BY) license (http://creativecommons.org/licenses/by/4.0/). 